\title{
CHANGING APPROACHES TO INDIGENOUS KNOWLEDGE AND ITS RELATIONSHIP WITH SCIENTIFIC KNOWLEDGE
}

\author{
Ngo Thi Phuong Lan*
}

\begin{abstract}
ABSTRAK
Ketika mengkaji kearifan lokal (atau pengetahuan masyarakat lokal), para peneliti sering mempertimbangkan kontrasnya dengan ilmu pengetahuan dari sudut pandang bahwa kearifan lokal biasanya terbelakang atau unggul kalau dipertimbangkan dari keberlanjutannya. Menurut saya, kita harus mempertimbangkan kondisi-kondisi tertentu ketika penduduk menggunakan kearifan lokal dan/atau ilmu pengetahuan. Dari kajian etnologi yang dilaksanakan pada tahun 2012 dan 2013 tentang kearifan lokal masyarakat suku bangsa Ma dan suka bangsa Stieng yang termasuk dalam rumpun bahasa Mon-Khmer di propinsi Binh Phuoc, Vietnam, kami ingin melakukan pengertian kembali konsep kearifan lokal, pengkajian hubungan antara kearifan lokal dan ilmu pengetahuan dan penganalisisan perubahan kearifan lokal di era sekarang ini. Saya berpikir bahwa kearifan lokal bukan ilmu yang tetap melainkan tergantung pada kuatnya kondisi ekonomi dan sosial di masa itu. Dalam kehidupan sehari-hari, penduduk setempat menghubungkan kearifan lokal dan ilmu pengetahuan untuk mengarahkan perubahan dalam kehidupan mereka.
\end{abstract}

Kata kunci: kearifan lokal, pembedaan kearifan lokal dan ilmu pengetahuan, suku bangsa Stieng, suku bangsa Ma, Vietnam

\begin{abstract}
Prevailing views on indigenous knowledge (IK) rely on a binary contrast between indigenous knowledge and scientific knowledge (SK), where the former is either dismissed as backward or judged superior in terms of its sustainability. I assert instead that we must examine the specific conditions under which people invoke indigenous and/or scientific forms of knowledge. Based on an ethnographic study of the IK of two Mon-Khmer speaking ethnic minority populations, the Xtiêng and the Mạ, in Binh Phuoc province of Vietnam, conducted in 2012 and 2013, this paper re-examines the definition of IK, exploring the relationship between IK and scientific knowledge (SK), and analyzing the changing nature of IK in the present context. In so doing, I suggest that IK is not a static body of knowledge but depends substantively on socio-economic conditions. In local people's daily lives, they both use IK and SK as resources for navigating their changing life-worlds.
\end{abstract}

Key Words: indigenous knowledge, dichotomy between indigenous knowledge and scientific knowledge, the Xtiêng, the Mạ, Vietnam

\footnotetext{
* University of Social Sciences and Humanities, Vietnam National University, Ho Chi Minh City
} 


\section{INTRODUCTION}

Located in the southeast of southern Vietnam, Binh Phuoc province is home to the Xtiêng, the Cho Ro and the Mạ, all of whom claim to be indigenous to this area. Although the Mạ is said to be an indigenous ethnic group of Lam Dong province, due to the proximity of Binh Phuoc to Lam Dong, a group of the Mạ settled in Binh Phuoc province after the state policy of encouraging permanent settlements instead of shifting cultivation. The Mạ living in Bu Dang district of Binh Phuoc said that this area was on the past route of their pattern of shifting cultivation from Nam Cat Tien forest of Lam Dong to Binh Phuoc, along the Dong Nai river. Based on our study of the present situation of the Xtiêng and the Mạ's indigenous knowledge (IK) in Binh Phuoc, we re-examine the definition of IK, explore the relationship between IK and scientific knowledge (SK), and analyze the changing conditions of IK in the present context.

Our study was conducted in 2012 and 2013 in Bu Dang and Loc Ninh districts of Binh Phuoc province, home to the Xtiêng and the Mạ. We mainly used qualitative methods of interviews and observations to collect data. We chose two communities, one Xtiêng and one Mạ for studying. It is true that, at present, the Xtiêng and the Mạ are no longer isolated groups each with an associated IK, but they co-exist with other ethnic groups who migrated from other places. Moreover, due to many state policies which affect ethnic groups, these communities are increasingly subject to the state's control and governance. Therefore, under these new socio-economic conditions, these ethnic minority groups lend themselves to an examination of the changes affecting indigenous knowledge. We conducted interviews with both elderly and young people, both male and female and both local authorities and lay people in order to have a variety of views on the issue.

Although we can understand culture in many different ways, it cannot be detached from the concept of nature. From this perspective, culture is seen both as a means and result of human adaptation to an environment. Yet this seemingly basic premise has generated two fundamentally different ways of understanding the process of adaptation. The first approach emphasizes human capabilities in transforming and conquering nature. It is often associated with Westerern SK and upheld as a standard for the rest of the world to follow. The first view orders IK and SK in an evolutionary or teleological scheme in which IK precedes SK. In the 1950s and 1960s this view was dominant, especially among theorists of development who saw indigenous and traditional knowledge as "ineffective, inferior, and an obstacle for development" (Agrawal, 1995:413). Within this framework, SK was considered the key to development. IK was thus constructed as something to be overcome and supplanted by SK, which represents modernity and development. However, SK has not fully accounted for human adaptation.

Since the Second World War and the subsequent spread of development programs the world over, scientists and policy-makers have began to question the role of science, the power of technology, and the effectiveness of institutional models in bettering people's lives. In the post-development era, local knowledge and technologies are seen as better strategies than universal knowledge regimes in combating poverty and underdevelopment. Therefore, the second approach instead validates IK and views IK as equally important as SK, stressing not the universal or general applicability of knowledge but rather its specificity in terms of time and place. According to this view, IK is distinguished from SK and its usefulness is compared and contrasted to that of SK within the local context, thereby demonstrating that IK is a better adaptive strategy. Proponents argue that IK helps natural- resource users live in harmony with nature and to use it sustainably. Indigenous knowledge has thus become a new term in the lexicon of development, often appearing alongside "economic growth," "growth with equity," "appropriate techniques," "participant development," "sustainable development" (Agrawal, 1995:413, 417). The shift to IK has been influential in Vietnam over the past decade. Many studies of IK have been conducted with the hope that it will be a useful source for development programs in specific localities (see Vuong, 1998; Pham, 2003; Nguyen, 2012; Pham and Hoang, 2009). In sum, IK is seen as an alternative solution to the problem of sustainable and appropriate 
adaptation to specific environments through which people seek to co-exist with but not conquer nature.

The persistent dichotomy between IK and SK may in fact blind us to how people actually draw on different ways of knowing. Many scholars argue that "what is today known and classified as indigenous knowledge has been in intimate interaction with western knowledge at least since the fifteenth century" (Wallenstein, 1974, Wolf, 1982, Abu-Lughod, 1989) and their contact was "a fact of life from as early as thousands of years ago" (Levis-Strauss, 1955 cited in Agrawal 1995:422). Therefore, in my view, the binary between IK and SK is very arbirtary. In our study of the local population's IK in Binh Phuoc province, these two types of knowledge are not opposed but complement each other, co-exist, and intertwine in people's adaptation strategies. Moreover, when analyzing the usefulness of IK to people's lives, I assume that in the present context of intensive acculturation and strong influence of state control, we have to pay attention to the existing conditions which shape the ways people invoke IK as a meaningful strategy. The case of Binh Phuoc province of Vietnam shows that the rapidly changing socio-economic conditions of local inhabitants can, in fact, lead to the diminishing use of IK in their everyday life.

\section{INDIGENOUS KNOWLEDGE: TERMS AND CONTENTS}

Indigenous knowledge is not the only term in vogue to designate how people have adapted to specific environments. Scholars also use allied terms. Aside from the term IK, scholars have employed local knowledge (Nguyen, 2012; Pham, 2003; and Tran, 2005), traditional knowledge (Sutton and Anderson, 2004) or indigenous technique knowledge (Institute of Ecological Economics, 2000; Howes and Chambers, 1980). These terms have also influenced development work. A practitioner of IK development (United Nations, 2004) assumes that traditional knowledge refers to the knowledge, innovations and practices of a local community manifested in their way of living, a definition not unlike that of academia.

Most of the studies have focused on enumerating the characteristics or components of IK. For example, Ellen (2004:412-413) asserts that
IK originates from localities and thus is the sum of certain experiences that reflect the knowledge produced by people living in these localities, the result of practical relationships with nature in local daily lives. Warrant (1991:1) likewise assumes that IK is local knowledge-knowledge of a certain society or culture and thus substantively different from an international knowledge system produced by universities, state-based institutions, and private companies. And as people draw on IK for making decisions in diverse fields such as agriculture, health care, food, education, and natural resource management, this knowledge is then verbally passed through generations. In Vietnam, Hoang Xuan Ty and Le Trong Cuc (1998) have defined IK as the knowledge system of indigenous peoples or communities in specific areas; they exist and develop within certain conditions that affect lives of all members of the community in a defined geographical area. Anthropologists who take IK as an important subject of their studies pay attention to both natural and social characteristics of IK. In their view, IK or folk knowledge, ethno- knowledge is "all knowledge, responses to the social and natural environment in each locality and area. Those pieces of knowledge are accumulated, practiced, selected, added, developed and passed from generation to generation in society. Local knowledge is of local ethnic groups who co-exist in the same ecological or culture area" (Nguyen, 2012:14-15).

Generally there are two approaches to describing the contents of IK. The first contrasts IK with SK by generating lists or describing the contents of IK in the hope such lists will help development programs at the local level. These lists focus on the learning system (indigenous methods of imparting knowledge), local organizations (traditional institutions for environmental management, traditional laws, taboos, rituals, and community controls on harvesting), local classification and quantification (local definitions and classification of phenomena and local flora and fauna, indigenous counting and quantifying), human health (nutrition, disease classification systems, traditional medicine, the use of herbal remedies), animals and animal disease, water (traditional water management and water conservation systems), soil (soil conservation practices, the use of specific species for soil conservation), agriculture (indigenous indicators 
to determine favorable times to prepare, plant, and harvest gardens, seed storage...), textile and local crafts... (For more examples, see Grenier, 1998: 2-3).

The second approach pays attention to IK as a systematic set of practices and beliefs. Specifically, it focuses on the interaction of local cosmology and living environment which has given shape to IK. The specific cosmology enhances the particular locality or the characteristics of indigenousness. Pamela McElwee (2010:1) claims that the majority of IK/TEK studies in Vietnam only selectively employ the concept of IK as of a static nature [with hardly any change], focusing on naming and classification [flora and fauna] or on managing resources by traditional laws, without any effort to understand the epistemological world through which IK is formulated. She proposes that IK should be approached as a comprehensive cosmology which needs to incorporate knowledge of rituals, religion, and beliefs. This call is familiar to anthropologists who have long advocated for such a holistic approach. Today in Vietnam, anthropologists and ethnologists approach IK as a total system (see Nguyen, 2012).

What characterizes these definitions of IK is their focus on "the local" or "indigenous" characteristics of knowledge relating to a certain environment or habitat. Some scholars prefer the term "local" over "indigenous," especially in the context of rapid social integration. However, Ellen and Harris (2010:3-4) assert that although the term "local" seems to be neutral it is not suitable to refer to the basic characteristics of this type of knowledge. Similarly, many authors prefer the term "traditional" but still use the term "indigenous" to refer to the specific. In this paper, we use terms "indigenous" and "local" interchangeably. "Indigenous" refers to long- standingness while "local" emphasizes the particular geographic locale.

Indigenous knowledge is an important theme in anthropology which has long emphasized local communities. Like other traditional dichotomies such as primitive-civilization, traditional-modern, Western- non-western, IK and SK are often constructed in binary opposition. However, among anthropologists, this opposition tends to valorize IK in comparison to SK or at the very least to be cautiously optimistic regarding the value of IK.
In other words, IK is not seen inferior, but often superior or at least equal to SK.

Through the case of the Ma and the Xtieng in Binh Phuoc province of Vietnam, we learn that IK is the total sum of knowledge that inhabitants in a specific environment use to adapt to their environment. IK reflects the adaptations, interactions, and responses of people to specific environments and this body of knowledge is shaped by the local cosmology. For example, living in a mountaineous environment, the Ma and the Xtieng have accumulated and developed the body of knowledge needed to cultivate rice and other grains. They learned that "red color" land was suitable for dry rice while "grey color" land was good for wet rice. Traditionally, having an unadvanced technology, these peoples have relied much on nature for their subsistence. As a result, they invented a useful system of gods in their cosmology that would help them to control crops and their lives. These gods included god of forest, god of rain, god of wind, god of river, god of thunder, god of earth, god of spring and the like. It means that their living reality "creates" their accordingly spiritual lives. In turn, this "created" world impacts back on people's daily behavior.

\section{DISENTANGLING INDIGENOUS AND SCIENTIFIC KNOWLEDGE}

While the distinctions between the two types of knowledge certainly exist, in reality, they are not so easily disentangled. In our two- month qualitative study in the Xtiêng and the Mạ communities in Binh Phuoc in May 2012 and June 2013, we examined how SK permeates and influences every aspect of indigenous people's everyday and ritual life. Ethnic groups such as Mạ, Xtiêng, Mnong in Bu Dang and Loc Ninh districts of Binh Phuoc province, at present, rely heavily on modern health care in their individual and family health practices (e.g., family planning, healing diseases, perception of hygiene and pollution). Likewise, in their agricultural production, indigenous people have also applied new high-yielding rice, planted cash crops, and used chemical fertilizers to improve their crops' productivity. How then can researchers determine what counts as IK and what counts as SK?

I share with many scholars the view that the 
division between IK and SK can be arbitrary. In my view, the distinction between these two types of knowledge simply reiterates their purported origins when, in fact, they are intertwined and enjoy a mutually constitutive relationship. The combination of these two types of knowledge in people's daily lives results from economic processes, the availability of resources associated with both types of knowledge, and the decision- making processes that people engage in when drawing on their available resources and knowledge. An example of how ethnic groups employ health care in Binh Phuoc province will illustrate this flexible combination. Even though people rely heavily on the network of health clinics, pharmacies, and hospitals for their health care, they still also use traditional remedies. In some cases, herbal remedies are said to be more effective than western medicine. Local perception of this combination is that "each medicine has its own good points. Many people do not have enough money to buy western medicines, so they have to rely on the traditional [herbal remedies] but only for minor illness, they have to go to hospital if they suffer severe illness." Another respondent reiterated a similar view: "if we have herbs at home we just spend time obtaining and preparing it without spending any money. Although medicines given by doctors from hospital help us to recover more quickly, herbal remedies obtained from the forest will keep us more healthy, taking western medicines is very costly" (Female, aged 45, Mạ, Bu Dang, Binh Phuoc province). Thus approaches that attempt to separate and order IK and SK cannot account for the flexible ways in which people draw on both knowledge regimes for their well-being.

Similar trends characterize agricultural production as well. A majority of local people in Binh Phuoc work in agriculture. People tend both gardens next to their houses and fields far from home; they often go to work in the fields and gardens far from their home. Each household can have several garden plots and fields located at different places. People go to work in the morning and go home in the evening. What we found in our study is that people draw on and use specific types of knowledge depending on its availability, amply illustrated by one respondent: "I often use traditional medicine made of herbs whenever I go to work in the fields. If I stay home, western medicines from health clinics or drugstore are available within my reach. At home if we get sick or hurt, western medicine and treatment are available, but when we go to the field which is far from home, there is no medicine for instant remedy. Therefore, we have to rely on herbs found in the forest" (Male, aged 55, Mạ ethnic group, Binh Phuoc).

Depending on their economic conditions and the availability of resources, people will decide to use one kind of treatment over another, traditional or modern. People draw on both IK and SK to determine their course of action. The successful story of a local woman's illness treatment illustrates for this point.

"At present, although people rely on western or modern treatment from hospital, if doctors cannot cure the illness, we willgo to anyone who can. For example, when I suffered from kidney illness, I went to hospital but they gave up (e.g., could not cure me). My husband went to the forest to get some herbs for me to use continuously for two or three months. Later I felt better. Finally, I went to the hospital to check, doctors said I have recovered from the illness" (Female, aged 40, Xtiêng ethnic group, Binh Phuoc province).

In addition to demonstrating that IK cannot be readily disentangled from SK, our study shows that IK does not emerge out of a particular environment but rather is produced out of interactions with different modes of IK from other groups or localities. The acculturation takes place as a result of processes of living alongside and marrying into other ethnic groups from other places who have since migrated to Binh Phuoc. According to statistics, at present, there are many groups such as Kinh, Tay, Thai, Hoa, Khmer, Muong, Nung, Hmong, Dao, San Chay, and Cham who migrated to Binh Phuoc from other places in the 1980s and 1990s (Binh Phuoc statistic office, 2011). In this regard, the process of producing a local body of knowledge is not only one of internal development but also involves the cross-fertilization of beliefs and practices among different groups. In our study, the Xtiêng and Mạ in Binh Phuoc province expanded their knowledge of herbal remedies as the result of learning from other ethnic groups such as the Kinh and 
the Dao who migrated from Northern provinces to Binh Phuoc. Binh Phuoc cannot be considered an isolated area inhabited by only one of group of people who have access to indigenous knowledge that evolved organically. Rather, what we observed were multiple sources of influence that could all be gathered under the rubric of IK.

Yet we also recognized that in addition to the characteristics described above, our study also highlighted the decline of IK in the context of intensive regional and economic integration fostered by Vietnam's rapid economic development.

\section{THE CHANGING NATURE OF INDIGENOUS KNOWLEDGE IN THE CONTEMPORARY ERA}

Although scholars recognize the crucial importance of IK, our study shows that these forms of knowledge are declining in many aspects of local life. Even though our study indicates that IK is a resource, one highly linked to adaptations to a specific environment, these adaptations can have significant effects on the value people associate with it. In our study of IK, we focused both on ecological and spiritual changes as a consequence of many ongoing socio-economic changes taking place in Binh Phuoc province. In our opinion, these two changes are influential factors in the "decline" of IK.

The 1980s marked a remarkable ecological shift in the lives of local inhabitants in Binh Phuoc. State-based policies encouraged ethnic groups to adapt sedentary lifestyles and plant cashew and later rubber tree as cash crops to supplement their traditional agricultural practices. In the following two decades, subsistence practices of peoples in Binh Phuoc province included clearing the forest or barren hills to plant rice, maize, cassava, sugar cane, gourd, yam and the like. People mainly plant rice at low elevations (colloquially called bưng or thung) close to streams or rivers, and plant cashew and rubber trees at higher elevations with red soil. In other places in Binh Phuoc, people plant rice, maize or cassava alongside the rubber seedlings while waiting for the rubber trees to mature. However, the yield of rice crops on these pieces of land is dependent on adequate rainfall. Many households reported that they were not able to harvest any rice when there was a drought because of the lack of an irrigation system. Cashew, pepper, coffee and later rubber trees were consequently introduced by the government with the aim of improving household incomes. While industrial trees are planted for cash, the rest of cultivated plants are mainly used for households' consumption.

If the early 1980s marked the shift to sedentary living and an emphasis on cash crops, then the first decade of the twenty-first century marked a significant change of forest tenure and its associated forms of exploitation. According to local people, they used to "exploit and till" in the forest. Presently, with the state's reallocation policy, access to the forest is allocated both to private and stateowned stakeholders. Many areas of natural forest have been turned into plantations where rubber trees predominate. With this new type of ownership, local people who do not have a plot of land or access to land to till cannot rely on the forest for their subsistence as they had in previous decades.

In sum, the integration of people into national development programs has created significant changes to the ecological system which in turn has influenced the existence of IK. In the past, local inhabitants' IK related closely to subsistence practices; today, however, the shift to cash crops (e.g., cashew, coffee, and rubber) has encouraged the use of SK in terms of seedlings as well as the use of fertilizer, pesticides and herbicides to ensure high yields. In other words, what our study demonstrates is how market production creates the conditions for dependency on SK. While IK is heralded as a set of diverse and adaptive strategies that foster biodiversity, we have observed that this diversity is on the decline with the shift from subsistence-based farming to plantations that favor mono-crop cultivation.

A trend similar to the ecological transformations described above can be seen in people's adoption of Protestant and Catholic religions. The shift in religious life has also encouraged different responses to their spiritual world, manifested in their daily lives through ritual performance. Ethnic groups in Binh Phuoc province mainly follow Protestantism (for example, $75 \%$ of the households in Dong Nai commune of Binh Phuoc are Protestant) (Binh Phuoc Statistics Department, 2011). According to our interviews, people were introduced to Protestantism and Catholicism in the late 1980s. 
With their new cosmologies, local people shifted from poly-deity-beliefs with their concomitant rituals to the practice of "only worshiping Jesus." Rituals as a form of local response to their spiritual world have, like the agricultural practices described above, given way to new forms of expression. In the past, people made offerings to deities or spirits as a way of healing patients. With the encouragement and policies of the government and priests, ethnic groups presently rely mainly on the modern health care system. People have shifted from attributing misfortune and illness from various "ghosts and spirits" to belief in "Christ." While hùm shamans used to be "health specialists," at present, people now recognize doctors and priests as authorities over their physical and spiritual well-being. Moreover, for native peoples in Binh Phuoc, the most important traditional ritual was "Lễ mừng Lúa Mới" (celebrating new harvest) to thank Rice Spirit, other relatives and people in the "bon" (village) who have shared with them during the working year. This ritual was performed either at the household or village level from the end of the year to the first month of the new lunar year, which coincided with the spring harvest. The Xtiêng in Loc Ninh district of Binh Phuoc reported that because rice was their staple food, in the past they cultivated several kinds of rice with different harvest and cultivation times, planting during the rainy season. This way of practice ensured them a rice supply. When they harvested the first crop, they would celebrate it with the specific ritual for celebrating the new harvest and when they finished all their harvest, they also performed the ritual to celebrate the time of "lúa lên nhà" (rice coming to the house). On this occasion, neighboring villages invited each other to enjoy whatever delicious food they had. Typical foods used at this ritual at the village level were sticky rice or rice steamed in bamboo, wild plants, herbal-fermented wine, and buffalo meat or pork. They enjoyed these festivities to the sound of gongs. At the household level, "depending on their economic conditions, people could sacrifice any animal (normally chickens) they had. If they were poor, they could offer vegetables... It was fine... We made offerings to wish our ancestors to enjoy and to bless our household to have much more rice next year... to invite our neighbors to enjoy with us", "to make offerings to thank heaven and earth, ancestors for a fruitful harvest and to ask for a good harvest next year. This was the occasion for people to meet and to share with each other after a hard working year" (Male, aged 42, Ma ethnic group, Binh Phuoc). At present, along with changes in agricultural and religious practices as mentioned above, the ritual of celebrating the New Harvest has been replaced by celebrations of Noel and Easter, two holidays associated with Protestant and Catholic religions. In the past, people would wear new clothes and traditional dress on the occasion of agricultural rituals; now they do so on Noel. Those households that depend on rice cultivation still practice the traditional agricultural rituals but in a different form at household level. They pray to the Jesus instead. In this case, IK may be said to be in decline not because it loses its position to scientific knowledge but rather because of changes in the religious lives of those people who are credited with having produced and maintained IK as a distinct form of knowledge.

\section{CONCLUSION}

In general, a more sophisticated approach to the study of IK among populations undergoing rapid processes of change is needed. Indigenous knowledge represents not only a specific adaptation to natural and social environments but in the context of intensive integration currently underway in Vietnam, the local cannot be understood as a cultural isolate, but rather a framework subject to constant negotiation, both from other bodies of IK as well as SK. At the same time, our study suggests that the decline of local people's IK is not because of the rise of SK as the teleological view suggests, but because of the ecological, social and spiritual changes in people's daily lives. So while people draw on various aspects of SK and IK, thus demonstrating that IK is not a static, immutable body of knowledge, it is still strongly influenced by existing conditions. In the present context of the rapid integration of many ethnic groups and communities in the market economy, we have an obligation to pay much attention to these conditions. In so doing, we may be able to tease out how the local or indigenous readily adapts in the context of intensive cultural exchanges. 
Acknowledgement:

The author wishes to thank Prof. Allison $J$. Truitt at Department of Anthropology, Tulane University-The United States and Prof. Patrick McAllister, Professor of Anthropology, University of Canterbury, New Zealand for having read and make useful comments for the earlier draft of this paper.

\section{REFFERENCES}

Abu Lughod, J. (1989). Before European Hegemony: The World System A.D. 1250-1350. New York: Oxford University Press.

Agrawal, Arun. (1995). "Dismantling the Divide between Indigenous and Scientific Knowledge". Development and Change. Vol 26 (1995), 413-439.

Binh Phuoc Statistics Department. (2011). Kết quả điều tra tình hình cơ bản hộ gia đình dân tộc thiểu số và thực trạng cơ sở hạ tầng các xã có đồng bào dân tộc thiểu số có đến 1/1/2011, huyện Bù Đăng, tỉnh Bình Phước: Kết quả chủ yếu. (Results of Baseline Study on Ethnic Minority Households and the Present Situation of Infrastructure at Communes Where lives Ethnic Minority Group up to 1st January 2011, $\mathrm{Bu}$ Dang district, Binh Phuoc province: Main Results)

Bui, Hoai Son (2010). Đôi nét về khái niệm tri thức bản địa. (Some Thinking on the Concept of Indigenous Knowledge). Tạp chí văn hóa nghệ thuât (Art Culture Review). No. 308

Ellen, Roy và Harris, Holly. (2010). Giới thiệu (Introduction). In Tri thức bản địa về môi truờng và những biến đổi: các quan điểm nhân học phê phán. (Indigenous Environmental Knowledge and Its Transformation: Critical Anthropological Perspectives), edited by Roy Ellen, Peter Parkers and Alan Bicker. Hanoi: Thế Giới Publisher

Grenier, Louise (1998). Working with Indigenous Knowledge: A Guide for Researcher. InternationaDevelopmenResearclCenter

Hoang, Xuan Ty and Le, Trong Cuc (1998). Kiến thức bản địa của đồng bào vùng cao trong nông nghiệp và quản lý tài nguyên thiên nhiên. (Indigenous Knowledge of Agriculture and Natural Resource Management of Peoples in HighElevation).Hanoi:NongnghiepPublisher

Howes, M. and R. Chambers. (1980). Indigenous
Technical Knowledge: Analysis, Implications and Issues. In Indigenous Knowledge Systems and Development, edited by D. Brokensha, D. Warren and Werner Lanham. University Press of America.

Institue of Economic Ecology. (2000). Sổ tay luu giũ và sủ dụng kiến thức bản địa. (Handbook of Reservation and Apllication of Indigenous Knowledge). Hanoi: Nong Nghiep Publisher

McElwee, Pamela. (2010). "Việt Nam có tri thức bản địa" không?" (Does Vietnam have indigenous knowledge?). Hiện đại và động thái của truyền thống ở Việt Nam: những cách tiếp cận Nhân học. (Modernities and Dynamics of Traditions of Vietnam. Volume 1, 1-19. Vietnam National University, Ho Chi Minh City Press.

Ngo, Thi Phuong Lan. (2006). "The Impacts of Market Economy on Social Relations: a Perspectove from Household Pottery Production in Lai Thieu, Binh Duong province, South of Vietnam." Humaniora, Volume 18, No.2, 178190

Nguyen, Ngoc Thanh. (2012). Tri thức địa phuoong của người dân sống trong vườn quốc gia và khu bảo tồn thiên nhiên. Social Science Publisher.

Pham, Quang Hoan. (2003). Tri thức địa phương của các dân tộc thiểu số Việt Nam" (Local Knowledge of Ethnic Minority Groups in Vietnam). In Dân tộc học Việt Nam trong thế kỷ 20 và nhũng năm đầu thế kỷ 21 (Vietnam Ethnology in the 20th Century and Early Years of the 21st Century), edited by Khong Dien. Hanoi: Khoa hoc Xa hoi Publisher

Pham, Quoc Hung và Hoang, Ngoc Y. (2009). Nghiên cứu tri thức bản địa của người Mông tại khu BTTN Hang Kia-Pà Cò, tỉnh Hòa Bình trong bảo vệ rừng. (Research on the Role of Indigenous Knowledge in Environmental Protection of the Mong at Hang Kia-Pà Cò Natural Reservation Area, Hoa Binh Province. Research Report. Ha Noi: Center for Human and Nature.

Sutton, Mark Q. and Anderson, E.N. (2004). Introduction to Cultural Ecology. AltaMira Press

Tran, Hong Hanh. (2005). Tri thức địa phương: sự tiếp cận lý thuyết. (Local Knowledge: Theoretical Approaches). Tap chi Dan Toc hoc (Ethnology Reviews. No. 1, 22-23

Vuong, Xuan Tinh. (1998). Tập quán bảo vệ rừng và nguồn tài nguyên với việc xây dựng quy ước làng bản hiện nay của hai dân tộc Tày-Nùng (The Customs of Forest and Natural Resources Protection and Compiling Village Regulations of the Tay and the Nung). In Kiến thức bản địa của các dân tộc vùng cao (Indigenous 
Knowledge of Ethnic Minority Groups in Mountainous Areas). 221-250. Hanoi: Nong nghiep Publisher.

United Nations on Trade and Development (Twarog, Sophia \& Kapoor, Promila eds) 2004. Protecting and Promoting Traditional Knowledge: Systems, National Experiences and International Dimensions. United Nations Publication.
Wallerstein, I. (1974). The Modern World-System. I. New York: Academic Press

Warren, D. M. (1991). "Using Indigenous Knowledge in Agricultural Development". World Bank Discussion Paper 127. Washington, DC World Bank.

Wolf, E. (1982). Europe and the People without History. Berkeley: University of California Press 